\title{
Access, Uptake, Use and Impacts of Agrometeorological Services in Sahelian Rural Areas: The Case of Burkina Faso
}

\author{
Vieri Tarchiani ${ }^{1, * \mathbb{D}}$, Hamidou Coulibaly ${ }^{2}$, Grégoire Baki ${ }^{3}$, Cyriaque Sia $^{3}$, Sara Burrone ${ }^{1} \mathbb{D}$, Pinghouinde \\ Michel Nikiema ${ }^{4}$, Jean-Baptiste Migraine ${ }^{4}$ and Jose Camacho ${ }^{4}$
}

1 Istituto per la BioEconomia-Consiglio Nazionale delle Ricerche, 50145 Firenze, Italy; sara.burrone@ibe.cnr.it

2 Office National de la Météorologie, Nouakchott, Mauritania; coulibaly_hamidou@yahoo.fr

3 Agence Nationale de la Météorologie, Ouagadougou, Burkina Faso; grebaki@yahoo.fr (G.B.); siacyriaque@yahoo.com (C.S.)

4 World Meteorological Organization, CH-1211 Geneva, Switzerland; pmnikiema@wmo.int (P.M.N.); jbmigraine@wmo.int (J.-B.M.); jcamacho@wmo.int (J.C.)

* Correspondence: vieri.tarchiani@ibe.cnr.it; Tel.: +39-0553033711

check for updates

Citation: Tarchiani, V.; Coulibaly, H.; Baki, G.; Sia, C.; Burrone, S.; Nikiema, P.M.; Migraine, J.-B.; Camacho, J. Access, Uptake, Use and Impacts of Agrometeorological Services in Sahelian Rural Areas: The Case of Burkina Faso. Agronomy 2021, 11, 2431. https://doi.org/10.3390/ agronomy11122431

Academic Editor: Gabriele Cola

Received: 30 September 2021

Accepted: 25 November 2021

Published: 29 November 2021

Publisher's Note: MDPI stays neutral with regard to jurisdictional claims in published maps and institutional affiliations.

Copyright: (c) 2021 by the authors. Licensee MDPI, Basel, Switzerland. This article is an open access article distributed under the terms and conditions of the Creative Commons Attribution (CC BY) license (https:// creativecommons.org/licenses/by/ $4.0 /$ )

\begin{abstract}
Agrometeorological services, as part of weather and climate services, are expected to play a key role in supporting sub-Saharan agriculture facing climate change and variability. In the Sahel, smallholder farmers relying on rainfed crop production systems are particularly vulnerable to climate change and variability because of low resilience and coping capacity. The provision of agrometeorological services is growing across Africa, but they often remain inaccessible for the majority of smallholder farmers or are not very relevant to support on-the-ground decision-making. Our work aims to demonstrate the hypothesis that agrometeorological services can effectively improve agricultural productivity and sustainability provided that appropriate mechanisms are put in place to ensure access, uptake and action. The paper illustrates the case study of Burkina Faso, where the National Meteorological Service, with the support of the World Meteorological Organization, engaged in the provision of accessible, reliable and relevant agrometeorological services for farmers. The study demonstrates that farmers, even in remote rural areas, are willing to profit from weather and climate services for strategic and tactical decisions in agricultural management because of relevant economic benefit. These benefits can be summarized as a $40 \%$ reduction in production costs and a $41 \%$ increase in income. Results also highlight environmental positive impacts such as the reduction by $50 \%$ in the use of fertilizers. Nevertheless, the study concludes that in order to scale-up weather and climate services in West Africa, a new business model released from the development projects approach should be explored.
\end{abstract}

Keywords: weather and climate services; agrometeorology; agricultural development; West Africa

\section{Introduction}

Agriculture plays a key role in West Africa (WA), particularly in poor landlocked Sahelian countries such as Burkina Faso. The majority of smallholder farmers rely on rainfed crop production systems characterized by low productivity, low input levels and high vulnerability to climatic risks. In the past, such systems successfully adapted to changing climatic conditions. Nevertheless, climate change and variability, combined with population pressure, poverty and land degradation are reducing livelihoods' resilience and coping capacity. Within weather and climate services (WCS), agrometeorological services (AS) are acknowledged as powerful tools for developing farmers' resilience and sustain crop production [1-3].

During the last 10 years, the World Meteorological Organization (WMO) actively supported WA countries, including Burkina Faso, in the transition towards Climate Smart Agriculture through the operationalization of WCS. The approach builds on the concept of Agriculture Innovation Systems (AIS), a network integrating agricultural research, 
extension, education agencies and farmers, as well as other private and public actors such as Meteorological Service, media and NGOs (Non-Governmental Organizations) that promote innovation in agriculture [4]. The hypothesis is that WCS can effectively improve agricultural productivity and sustainability towards climate change and related risks, playing a critical role in meeting Sustainable Development Goals [5].

Relevant research and investments have been deployed in earth observation and modeling with the objective of implementing WCS for agriculture. The provision of WCS is growing across Africa [3], however, they remain almost inaccessible for a large part of smallholder farmers or, in the best case, are not very relevant to support on-the-ground decision-making [6]. Indeed, in developing countries and particularly WA, WCS production relies mainly on National Meteorological and Hydrological Services (NMHS), which are structurally facing large capacity and competency gaps [7]. According to many authors, besides technical capacities to develop the services, the main challenge remains the access to information by farmers [8] and trust of farmers in WCS, ensuring operational use for riskinformed decision-making $[6,9]$. Access in WA, in terms of farmers' capability to retrieve the information, relies mainly on local components of the AIS which are charged with bridging the gap between NMHS and local communities. Rural radios are still acknowledged as the main information channel for farmers $[2,10]$ followed by the extension service and local social networks [11]. Mobile phones and social media are gaining momentum [12], but are still not generalized in poor rural areas. Nevertheless, trust, in terms of credibility, accuracy and source of information, affects farmers' uptake and use of WCS [13]. During the last years, collaborative approaches for co-development of WCS are being deployed in order to include users early in the design of the services [2,14]. Vincent et al. [9] aim for a process of co-production implying an adaptation of the workflow "moving from supply-driven to demand-driven models" and applying an iterative model of co-learning establishing long-term relationships and trust between producers and users $[15,16]$.

All these aspects need to be analyzed for the evaluation of WCS in agriculture. The literature is quite rich in ex-post and ex-ante evaluations of WCS impacts $[17,18]$. Exante methods use models to estimate how potential uses of information could improve the productivity or socio-economic conditions of households, while ex-post methods use empirical approaches to directly estimate the benefits due to already existing WCS. All these methods do not usually deepen the causal relationship between information and outcomes. Indeed, the evaluation of WCS is particularly challenging because of the interaction of many components that vary considerably from year to year, from production system to production system, and even from community to community [17].

According to the logic model for WCS evaluation in agriculture developed by Vogel et al. [18], outcomes in terms of increased agricultural productivity are a cumulative indicator of the effectiveness of a complex process. Performance degradations at any of the stages of the process contribute to reducing the overall outcome of WCS. The use of such a logic model in the evaluation of WCS provides the opportunity to verify each step with users and adopt corrective measures if needed. Indeed, while the overall evaluation can be ensured by the assessment of the outcomes (e.g., yield increase), the evaluation of the process needs to be split in different steps where the first focuses on the quality of the information [19], the second on access [20], the third on uptake [21] and the last on ability to act [22].

Given the hypotheses that WCS produced by NMHS can effectively improve agricultural productivity and increase farmers' income, this paper analyzes the access, uptake and use by farmers of WCS produced by the Burkina Faso National Agency for Meteorology (ANAM) and finally it assesses the impact on agricultural productivity in terms of both cost reduction and income generation. The paper addresses also some environmental positive impacts enabled by the adoption of WCS. 


\section{Materials and Methods}

\subsection{Study Area}

The study site is the Municipality of Tenado, one of the three pilot sites of the CREWS project in Burkina Faso. Located in the West-Central Region of Burkina Faso, the area belongs to the Sudano-Sahelian climatic domain with total annual rainfall ranging from 600 to $900 \mathrm{~mm} /$ year. The duration of the rainy season does not generally exceed 6 months. The relief of the area is generally uneven, varying between 200 and $400 \mathrm{~m}$ a.s.l. as a whole; the vegetation of the area is characterized by shrub savannahs, tree savannahs and gallery forests. According to the last census in 2006, the population was 48,694 , corresponding to about 4900 rural households. Cereal farming, cash crops and trade are the main economic activities, while the most produced cereals are sorghum, millet, and corn.

In line with the CREWS approach, at this site, ANAM provided training for producers and breeders in the use of WCS through roving seminars [23,24]. Five were held in 2018 with an average of 70 people per session, another one in 2019 and one in 2020, and rain gauges were also distributed. In addition to the roving seminars for producers, training for agents of the extension services (agriculture, animal production, environment, municipalities) and radio agents in the use and dissemination of WCS was carried out at the site level. During 2018, 2019 and 2020 cropping seasons, ANAM produced WCS, including agro-meteorological advice and weather and climate forecasts. They were disseminated to farmers, in addition to training and awareness seminars, through rural radios and text and voice messages.

\subsection{Evaluation Approach}

As suggested by Perrels et al. [25], the evaluation method builds on the Weather Service Chain Analysis (WSCA) breaking down the flow from information generation to outcomes. WSCA is then applied to our specific use case: rainfed agriculture in the Municipality of Tenado. A use case is a description of what a specific user in a particular situation is looking to do or know to improve their business. The underpinning logic model represents the functional relationships between all the activities aimed at modifying farmers' decision-making in order to improve it and obtain social, environmental and economic benefits. As suggested by Vogel et al. [18], the logic model can be represented as follows in Figure 1.

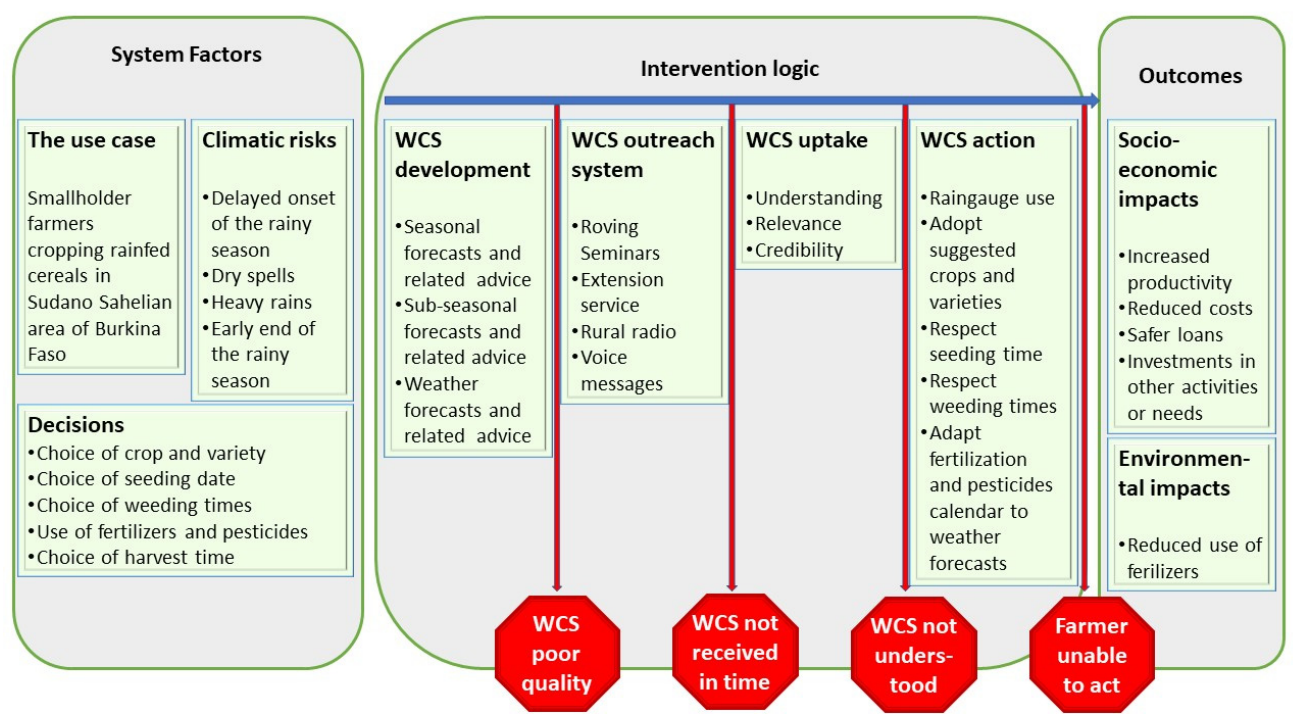

Figure 1. Logical model for the evaluation of WCS in Burkina Faso. Adapted from Vogel et al. (2017) [18].

In the case of CREWS, the use of a logic model is particularly useful. It explicitly defines the stepwise logic according to which WCS aim to effect changes in the decision- 
making process. Moreover, it allows each step to be tested against observation. Indeed, verification in stages is particularly important because the contribution of each specific activity to the overall change in outcome can be difficult to discern. In our case, once it is observed that WCS (i) has a suitable quality to be disseminated, (ii) are properly accessed by farmers, (iii) are understood and trusted, the=is study aims to assess socio-economic and environmental impacts. Therefore, evaluation of the WCS chain will make it possible to interpret and establish a causal link between services and observed impacts using the explanatory variables of the logic model (Table 1).

Table 1. WCS chain analysis.

\begin{tabular}{|c|c|c|c|}
\hline Step & Observed Variable & Research Question & Tools \\
\hline WCS Development & Quality of WCS & $\begin{array}{l}\text { Were WCS } \\
\text { appropriate to the } \\
\text { situation observed } \\
\text { ex-post? }\end{array}$ & $\begin{array}{l}\text { Confusion matrix } \\
\text { observed vs. } \\
\text { forecasted }\end{array}$ \\
\hline $\begin{array}{l}\text { WCS outreach } \\
\text { system, }\end{array}$ & $\begin{array}{l}\text { Access to WCS at } \\
\text { appropriate times }\end{array}$ & $\begin{array}{l}\text { Who had access to } \\
\text { what type of } \\
\text { information, factors } \\
\text { allowing or } \\
\text { constraining access, } \\
\text { gender and } \\
\text { socio-economic } \\
\text { differences? }\end{array}$ & $\begin{array}{l}\text { Survey of treated and } \\
\text { untreated groups } \\
\text { Key informant } \\
\text { interviews (radio } \\
\text { agents, broadcasting } \\
\text { system agents) }\end{array}$ \\
\hline WCS uptake & $\begin{array}{l}\text { Understandability, } \\
\text { relevance, credibility, }\end{array}$ & $\begin{array}{l}\text { What is users' } \\
\text { perception about } \\
\text { usability of WCS? }\end{array}$ & $\begin{array}{l}\text { Survey of treated and } \\
\text { untreated groups }\end{array}$ \\
\hline Action by farmers & $\begin{array}{l}\text { Agricultural practices } \\
\text { and investments }\end{array}$ & $\begin{array}{l}\text { What action has been } \\
\text { taken on WCS? }\end{array}$ & $\begin{array}{l}\text { Survey of treated and } \\
\text { untreated groups }\end{array}$ \\
\hline $\begin{array}{l}\text { Impacts on-farm } \\
\text { management }\end{array}$ & $\begin{array}{l}\text { Agricultural } \\
\text { productivity, } \\
\text { economic benefit, } \\
\text { environmental effects }\end{array}$ & $\begin{array}{l}\text { Which impacts do } \\
\text { WCS have on } \\
\text { farming? }\end{array}$ & $\begin{array}{l}\text { Survey of treated and } \\
\text { untreated groups }\end{array}$ \\
\hline
\end{tabular}

In the case of this study, we used an ex-post evaluation method for the 2019 and 2020 agricultural seasons in the Tenado pilot site, which benefited from the WCS provided by ANAM. The methodology used for the evaluation had already been tested in 2015 [4] and 2016 [14] in Niger, Mauritania, Ghana and Ivory Coast in the framework of the METAGRI (METeorological AGRIculture) project. The adopted ex-post evaluation is counterfactual, using a comparison between a treatment group and a control group, with the two groups having the same characteristics at the start of the study. The evaluation of treatment and control groups in the same system makes it possible to minimize climatic variability over time. In any case, the non-exclusivity of the information could make it difficult to compare decisions between the treated and untreated groups, because it complicates the identification of the control group without access to information, such as asked for in the randomized trial. Consequently, this approach was adopted on the assumption that the treatment is not the access to information but rather training in the use of the information itself. The control group is random and represents the entire population. The treatment group is also random, from the participants in training.

\subsection{Dataset}

The surveys were conducted in October 2019 and in November 2020 using structured questionnaires translated and administered in the local language by trained enumerators. Moreover, yield plots were placed in farmers' fields and yield was measured on site. The sample at the Tenado site consisted of surveys from approximately 300 farmers (150 treated 
and 150 control) in 12 villages for each year. Table 2 summarizes the quantitative variables used in the analysis for the whole sample, 2019 and 2020 considered jointly.

Table 2. Descriptive statistics for the whole sample (2019-2020).

\begin{tabular}{|c|c|c|c|c|c|}
\hline Variables & Obs & Mean & Std. Dev. & Min & Max \\
\hline Pilot group & 603 & 0.50 & 0.50 & 0 & 1 \\
\hline N. seedings & 603 & 2.01 & 0.82 & 1 & 4 \\
\hline Quantity of seeds $\mathrm{kg} / \mathrm{ha}$ & 603 & 32.05 & 7.90 & 19 & 53 \\
\hline $\mathrm{N}$. fertilizations & 603 & 2.40 & 0.90 & 1 & 4 \\
\hline $\begin{array}{l}\text { Quantity fertilizers } \\
\mathrm{kg} / \mathrm{ha}\end{array}$ & 603 & 78.34 & 31.75 & 38 & 150 \\
\hline Working days & 603 & 46.89 & 10.44 & 6 & 68 \\
\hline Yield kg/ha & 603 & 1195.80 & 238.24 & 95 & 1698 \\
\hline Costs (FCFA/ha) & 603 & $116,801.99$ & $31,194.30$ & 76,250 & 183,500 \\
\hline $\begin{array}{ll}\text { - } & \text { Seeds cost } \\
\text { (FCFA/ha) }\end{array}$ & 603 & $11,217.41$ & 2765.87 & 6650 & 18,550 \\
\hline $\begin{array}{ll}\text { - } & \text { Fertilizers cost } \\
\text { (FCFA/ha) }\end{array}$ & 603 & $35,253.73$ & $14,285.40$ & 17,100 & 67,500 \\
\hline $\begin{array}{ll}\text { - } & \text { Labor cost } \\
\text { (FCFA /ha) }\end{array}$ & 603 & $70,330.85$ & $15,658.59$ & 9000 & 102,000 \\
\hline Income (FCFA/ha) & 603 & $239,161.50$ & $47,648.53$ & 19,000 & 339,600 \\
\hline $\begin{array}{l}\text { Gross benefit } \\
\text { (FCFA/ha) }\end{array}$ & 603 & $122,359.5$ & $73,533.58$ & $-117,650$ & 255,050 \\
\hline
\end{tabular}

$(1 €=655.957$ FCFA $)$.

The market price of sorghum and the cost of seeds, fertilizer and labor were considered stable over the 2 years and in particular the sorghum price was 200 FCFA per $\mathrm{kg}$, while the costs were 350 FCFA for $1 \mathrm{~kg}$ of seeds, and 450 FCFA for $1 \mathrm{~kg}$ of fertilizer. Labor cost is accounted as the opportunity costs of working time considering that 1500 FCFA is the daily wage in agriculture. Income was computed by multiplying yield by the price of sorghum, while the gross benefit is the income minus the costs. Table 3 shows the same variables by year of the survey. Almost all variables show minimum variation over years except for the fertilizations. Despite the costs decrease, the gross benefit in 2020 is lower than that in the previous year owing to lower yields.

Table 3. Descriptive statistics by year of survey.

\begin{tabular}{lcc}
\hline \multirow{2}{*}{ Variables } & $\mathbf{2 0 1 9}$ & $\mathbf{2 0 2 0}$ \\
\cline { 2 - 3 } & Mean & Mean \\
\hline Pilot group & 0.50 & 0.50 \\
N. seedings & 2.00 & 2.02 \\
Quantity of seeds kg/ha & 33.93 & 30.16 \\
N. fertilizations & 2.71 & 2.09 \\
Quantity fertilizers kg/ha & 91.24 & 65.40 \\
Working days & 47.64 & 46.13 \\
Yield kg/ha & 1271.59 & 1119.76 \\
Cost (FCFA/ha) & $124,392.70$ & $109,186.00$ \\
- Seeds cost (FCFA/ha) & $11,876.82$ & $105,55.81$ \\
$\quad \quad$ & $41,057.28$ & $29,430.90$ \\
$\quad$ Fertilizers cost (FCFA/ha) & & $69,199.34$ \\
$\quad$ Labor cost (FCFA/ha) & $71,458.61$ & $223,953.50$ \\
Income (FCFA/ha) & $254,319.20$ & $114,767.40$ \\
Gross benefit (FCFA/ha) & $129,926.50$ & 301 \\
Obs. & 302 & \\
\hline
\end{tabular}




\subsection{Statistical Methods}

To assess the impact of WCS on trained farmers, we computed the Intention to Treat (ITT) effect, this allows to tackle the problem of possible imperfect compliance, or in other terms whether individuals do not follow their treatment assignment, pilot or control group. To this end, we estimate Ordinary Least Squares (OLS) regressions where the outcome variable $y_{i t}$ is in turn, yields, benefit, income, costs and the use of the following inputs: seeds, fertilizer (measured in $\mathrm{kg}$ ), and labor (measured in working days) of the individual $i$ at time $t[26]$.

Our variable of interest is the dummy pilot ${ }_{i}$ assuming value 1 when the individual $i$ has been selected as a participant in the training offered by ANAM at time $t$. Since yields, income and costs may be affected by some effects related to the year in which data were collected, we include the dummy year 2020 $i t$ that is coded 1 depending on whether the observation refers to 2020 .

As a result, the model is the following

$$
y_{i t}=\beta_{1}+\beta_{2} \text { pilot }_{i t}+\beta_{3} \text { year } 2020_{i t}+\varepsilon_{i t}
$$

where $\beta_{2}$ represents the variation of the outcome variable $\left(y_{i t}\right)$ when the variable of interest $\left(\right.$ pilot $\left._{i t}\right)$ is equal to 1 . In our case, it measures the difference in the means of yield, benefit, income, costs, use of input (seeds, fertilizer, and labor) between farmers in the pilot $\left(\right.$ pilot $\left._{i t}=1\right)$ and control group ( pilot $\left._{i t}=0\right)$. As a result, $\beta_{2}$ indicates the impact of the treatment (the training). Finally, $\beta_{1}$ is the constant term and $\varepsilon_{i t}$ are the robust error terms. Regarding the outcome variables, this allows us to understand whether participation in the training has improved farmer sustainability in socio-economic and environmental terms.

The hypothesis to be tested is to find a positive and significant relationship between the training on WCS and the yields and thus between the training and income. On the contrary, we expect a negative and significant relationship between the training and costs. As a consequence, we expect an increase in the gross benefits as the overall effect.

Considering the yield, we control for other possible variables that are likely to affect it and thus we re-estimate Equation (1) including the following covariates: $\mathrm{kg}$ of seeds and fertilizers used and the number of working days. Since they do not have significant effects on the outcome variables, results are presented in Appendix A.

\section{Results}

Results are described according to the intervention logic model developed for the case study.

\subsection{Quality of WCS}

ANAM conducted statistical evaluations of the produced seasonal forecasts (SF) after the end of the 2019 and 2020 seasons using forecast performance scores. In the study area, probabilistic forecasts for both periods (June-July-August and July-August-September) correctly forecasted the observed 3-month cumulated precipitation (Table 4). In 2019, a normal season had been forecasted, and it was observed, while in 2020, an above normal season was forecasted and observed. We can therefore assume that the quality of WCS is suitable for dissemination to users.

Table 4. Seasonal forecasts 2019 and 2020 of cumulated precipitation (JJA: June-July-August; JAS: July-August-September).

\begin{tabular}{ccc}
\hline Period & Forecasted & Observed \\
\hline JJA 2019 & Normal & Normal \\
\hline JAS 2019 & Normal & Normal \\
\hline JJA 2020 & Above Normal & Above Normal \\
\hline JAS 2020 & Above Normal & Above Normal \\
\hline
\end{tabular}




\subsection{Access}

The results of the surveys show that $86 \%$ of trained farmers have regular access to understandable WCS during the 2019 and 2020 cropping seasons from May to October (Table 5). A slight difference is nevertheless observed between the two years, with a stronger percentage of farmers having access in 2019 rather than in 2020. This difference is probably related to the nature of the rainy season: since 2020 was an above normal season, farmers felt less the need to have agrometeorological information that is generally more useful in case of a dry season. The average gender distribution is $65 \%$ males and $34 \%$ females.

Table 5. Pilot farmers having regular access to understandable WCS during the whole cropping season.

\begin{tabular}{cccc}
\hline & $\begin{array}{c}\mathbf{2 0 1 9}(\mathbf{1 5 1} \\
\text { Observations) }\end{array}$ & $\begin{array}{c}\mathbf{2 0 2 0} \mathbf{( 1 5 0} \\
\text { Observations) }\end{array}$ & $\begin{array}{c}\text { Average 2019-2020 } \\
\text { (301 Observations) }\end{array}$ \\
\hline Total & $95 \%$ & $76 \%$ & $86 \%$ \\
\hline Males & $63 \%$ & $67 \%$ & $65 \%$ \\
\hline Females & $37 \%$ & $33 \%$ & $35 \%$ \\
\hline
\end{tabular}

Information is accessed mainly through community radios' broadcast, followed by roving seminars, direct contact with extension agents and text messages.

\subsection{Uptake}

During the three years of project activity, the users' perception of provided services evolved slightly. Indeed, at the beginning, the project faced resistance from many farmers who were used to base their decisions solely on their empirical knowledge. However, the project's willingness to facilitate the integration of local knowledge of climate information has been very helpful in convincing reluctant farmers. Today, in the project area, farmers no longer just wait for climate or weather information, but go in search of it. Informal feedbacks from users suggests that in Tenado, AS are now considered more than an agricultural input. Seasonal forecasts are eagerly awaited at the beginning of the season, as well as climate information for monthly, ten-day, weekly and daily monitoring, and special notices and alerts. This is made possible by the very strong collaboration of ANAM with the agricultural extension services at central and regional level, farmers' organizations and the local community radio (la voie du Sanguié).

\subsection{Action}

Action by farmers refers to strategic or tactical choices, the first being essential to properly plan the agricultural campaign and the latter necessary to optimize the resources used. In the sorghum rainfed system, $84 \%$ of farmers with access to the information used SF to choose crop varieties and toposequences to exploit and to prepare the land; $83 \%$ of them also declared to have used SF to choose the seeding time, and finally $82 \%$ used weather forecasts $(\mathrm{WF})$ for other cropping practices. In contrast, market gardeners are not yet as prone to use AS, indeed, only 55\% declared to have used SF for preparing the nurseries (Table 6).

Table 6. Use of WCS by pilot farmers (obs: observations).

\begin{tabular}{|c|c|c|c|c|}
\hline \multicolumn{2}{|c|}{ Decision } & $\begin{array}{c}2019 \\
\text { (151 Obs.) }\end{array}$ & $\begin{array}{c}2020 \\
(150 \text { Obs.) }\end{array}$ & $\begin{array}{l}\text { Average 2019-2020 } \\
\quad(301 \text { Obs.) }\end{array}$ \\
\hline \multirow[b]{2}{*}{ Strategic } & $\begin{array}{l}\text { Seeds variety, land } \\
\text { preparation, toposequences } \\
\text { based on SF }\end{array}$ & $82 \%$ & $86 \%$ & $84 \%$ \\
\hline & $\begin{array}{l}\text { Nursery establishment for } \\
\text { market gardeners based on SF }\end{array}$ & $45 \%$ & $65 \%$ & $55 \%$ \\
\hline \multirow[b]{2}{*}{ Tactical } & Seeding time based on SF & $80 \%$ & $86 \%$ & $83 \%$ \\
\hline & $\begin{array}{l}\text { Weeding, fertilization, } \\
\text { treatment times based on WF }\end{array}$ & $79 \%$ & $85 \%$ & $82 \%$ \\
\hline
\end{tabular}




\subsection{Impacts}

Table 7 shows the means of the variables by control and pilot groups for the whole sample (2019-2020). The quantity of seeds, fertilizer and number of working days decrease drastically among farmers in the pilot group. The effective use of WCS by trained farmers is likely to have improved input management skills.

Table 7. Descriptive statistics by pilot and control group (2019-2020).

\begin{tabular}{lcc}
\hline \multicolumn{1}{c}{ Variables } & Pilot & Control \\
\hline N. seedings & 1.47 & 2.53 \\
Quantity of seeds kg/ha & 24.97 & 39.10 \\
N. fertilizations & 1.72 & 3.07 \\
Quantity fertilizers kg/ha & 50.99 & 105.60 \\
Working days/ha & 37.25 & 56.48 \\
Yield kg/ha & 1400.31 & 991.98 \\
Cost (FCFA/ha) & $87,574.09$ & $145,933.10$ \\
- $\quad$ Seeds cost (FCFA/ha) & 8738.372 & $13,688.25$ \\
$\quad \quad$ & \\
$\quad \quad$ Fertilizers cost (FCFA/ha) & $22,947.01$ & $47,519.70$ \\
$\quad$ Labor cost (FCFA/ha) & $55,888.70$ & \\
$\quad$ Income (FCFA/ha) & $280,061.10$ & $84,725.17$ \\
Gross benefit (FCFA/ha) & $192,487.00$ & $198,397.40$ \\
Observations & 301 & $52,464.24$ \\
\hline
\end{tabular}

$(1 €=655.957$ FCFA $)$.

The main impacts on-farm management are summarized in Table 8. The odds column shows results without controlling for the year, while the even column includes them. The Pilot row reports the coefficient $\beta_{2}$ in Equation (1), which represents the difference in the mean of the dependent variables (columns) between the control and treatment groups. The Constant row reports the coefficient $\beta_{1}$ in Equation (1). Considering column 1, farmers in the Pilot group show yields $408 \mathrm{~kg} /$ ha higher than those in the control group. As for column 3, income in the treatment group is 81,664 FCFA/ha higher than in the control one. On average, the costs incurred by farmers in the treatment group are 58,359 FCFA/ha lower than those of farmers in the control one because of a net reduction of inputs amount (Table 9). Savings result in a reduction of production costs, while increased yield ensures an increase in income, and, as a result, benefits of pilot farmers (Table 8, column 7) are 140,023 FCFA/ha higher than those of farmers in the control group, corresponding to an increase by $267 \%$. Such a large difference should not be a surprise, because an important contribution comes from the opportunity cost of labor and fertilizer that pilot farmers saved thanks to WCS (Table 9). Globally, results show that WCS impact productivity positively by improving trained farmers' tactical and strategical decisions. Gross benefit results are higher in the Pilot group, indicating that WCS increase cropping profitability by reducing input overuse and increasing yields. Moreover, the reduction by $50 \%$ in fertilizers quantity represents an important environmental impact, reducing soil and groundwater pollution. 
Table 8. Impact of the training on yields, benefit, income and costs, coefficients of OLS regressions.

\begin{tabular}{|c|c|c|c|c|c|c|c|c|}
\hline & (1) & (2) & (3) & (4) & (5) & (6) & (7) & (8) \\
\hline & Yields (kg/ha) & Yields (kg/ha) & Income (FCFA/ha) & Income (FCFA/ha) & Costs (FCFA/ha) & Costs (FCFA/ha) & Benefit (FCFA/ha) & Benefit (FCFA/ha) \\
\hline Pilot & $\begin{array}{c}408.319 * * * \\
(9.987)\end{array}$ & $\begin{array}{c}408.068 * * * \\
(7.860)\end{array}$ & $\begin{array}{c}81,663.779 * * * \\
(1997.421)\end{array}$ & $\begin{array}{c}81,613.562 * * * \\
(1572.034)\end{array}$ & $\begin{array}{c}-58,359.026 * * * \\
(892.709)\end{array}$ & $\begin{array}{c}-58,384.448 \text { *** } \\
(640.057)\end{array}$ & $\begin{array}{c}140,022.805 * * * \\
(1818.168)\end{array}$ & $\begin{array}{c}139,998.010 * * * \\
(1714.141)\end{array}$ \\
\hline Year 2020 & & $\begin{array}{c}-151.151 * * * \\
(7.857)\end{array}$ & & $\begin{array}{c}-30,230.146 * * * \\
(1571.489)\end{array}$ & & $\begin{array}{c}-15,303.653 * * * \\
(639.970)\end{array}$ & & $\begin{array}{c}-14,926.493 \text { *** } \\
(1713.478)\end{array}$ \\
\hline Constant & $\begin{array}{c}991.987 * * * \\
(6.929)\end{array}$ & $\begin{array}{c}1067.562 \text { *** } \\
(8.596)\end{array}$ & $\begin{array}{c}198,397.351 * * * \\
(1385.809)\end{array}$ & $\begin{array}{c}213,512.424^{* * *} \\
(1719.233)\end{array}$ & $\begin{array}{c}145,933.113 * * * \\
(830.396)\end{array}$ & $\begin{array}{c}153,584.939 * * * \\
\quad(757.250)\end{array}$ & $\begin{array}{c}52,464.238 * * * \\
(1265.906)\end{array}$ & $\begin{array}{c}59,927.485^{* * *} \\
(1848.626)\end{array}$ \\
\hline Observations & 603 & 603 & 603 & 603 & 603 & 603 & 603 & 603 \\
\hline R-squared & 0.736 & 0.836 & 0.736 & 0.836 & 0.876 & 0.937 & 0.908 & 0.918 \\
\hline
\end{tabular}

Note: The coefficient $\left(\beta_{2}\right.$ in Equation (1)) of Pilot variable measures the difference in the mean of the values of the dependent variables (columns) between the control and treatment groups; Robust standard errors in parentheses; ${ }^{* * *} p<0.01,{ }^{* *} p<0.05,{ }^{*} p<0.1$; $(1 €=655.957$ FCFA $)$.

Table 9. Impact of the training on the use of seeds, fertilizer, and working days, coefficients of OLS regressions.

\begin{tabular}{|c|c|c|c|c|c|c|}
\hline & (1) & (2) & (3) & (4) & (5) & (6) \\
\hline & Seeds (kg/ha) & Seeds (kg/ha) & Fertilizer (kg/ha) & Fertilizer (kg/ha) & $\begin{array}{l}\text { Working } \\
\text { Days/ha }\end{array}$ & $\begin{array}{l}\text { Working } \\
\text { Days/ha }\end{array}$ \\
\hline Pilot & $\begin{array}{c}-14.142^{* * *} \\
(0.287)\end{array}$ & $\begin{array}{c}-14.149 \text { *** } \\
(0.241)\end{array}$ & $\begin{array}{c}-54.606^{* * *} \\
(1.316)\end{array}$ & $\begin{array}{c}-54.649 * * * \\
(0.786)\end{array}$ & $\begin{array}{c}-19.224 \text { *** } \\
(0.330)\end{array}$ & $\begin{array}{c}-19.227 * * * \\
(0.325)\end{array}$ \\
\hline Year 2020 & & $\begin{array}{c}-3.798 * * * \\
(0.241)\end{array}$ & & $\begin{array}{c}-25.927^{* * *} \\
(0.785)\end{array}$ & & $\begin{array}{c}-1.538 * * * \\
(0.325)\end{array}$ \\
\hline Constant & $\begin{array}{c}39.109 * * * \\
(0.202)\end{array}$ & $\begin{array}{c}41.008^{* * *} \\
(0.180)\end{array}$ & $\begin{array}{c}105.599 * * * \\
(1.154)\end{array}$ & $\begin{array}{c}118.563 * * * \\
(1.024)\end{array}$ & $\begin{array}{c}56.483 * * * \\
(0.304)\end{array}$ & $\begin{array}{c}57.253^{* * *} \\
(0.390)\end{array}$ \\
\hline Observations & 603 & 603 & 603 & 603 & 603 & 603 \\
\hline R-squared & 0.802 & 0.860 & 0.741 & 0.908 & 0.849 & 0.855 \\
\hline
\end{tabular}

Note: The coefficient ( $\beta_{2}$ in Equation (1)) of Pilot variable measures the difference in the mean of the values of the dependent variables (columns) between the control and treatment groups; Robust standard errors in parentheses; ${ }^{* * *} p<0.01$, $^{* *} p<0.05,{ }^{*} p<0.1$; $(1 €=655.957$ FCFA $)$.

The impact of the treatment is stable even when introducing the second variable "year $2020^{\prime \prime}$ that controls for interannual variability. For example, column 2 of Table 8 shows that the difference in yields between Control and Pilot groups remains $408 \mathrm{~kg} /$ ha even if, on average, yields in 2020 were $151 \mathrm{~kg} /$ ha lower than in 2019.

\section{Discussion}

In West Africa, some studies exist on the evaluation of WCS but few focus on Burkina Faso [8,26-29]. Tall et al. [17] analyzed six studies in their review of evaluations to assess the value of WCS for farmers. Vaughan et al. [3] analyzed 28 studies evaluating agricultural WCS in West Africa.

\subsection{Access}

Acknowledging the critical importance of WCS being properly accessed by farmers, the key factor is the communication channel that should be adapted to users [30]. The main barriers documented in the access are related to the availability by farmers of receiving devices such as radio, telephone, TV [31] or selected broadcasting channels such as radio coverage and mobile telephone coverage. [32,33]. A further challenge is that the information transferred through informal networks may be incomplete or distorted [17]. The non-exclusive nature of open access public WCS means that information can easily be transmitted along media, social and family networks, making it difficult to distinguish between those who receive the service and those who do not [22]. On the contrary, the choice of a specific dissemination channel can create gaps in reaching specific groups (e.g., farmers vs. pastoralists, men vs. women, young vs. adults). Indeed, it is well documented that challenges in accessing WCS may be compounded by gender, with women having less access than men [10,22,33-35]. Our study confirms this gap, even if specific actions have been undertaken, including women's groups and networks. Therefore, gender-specific needs still exist, in terms of both WCS needs and communication channels. The same 
applies to other vulnerable groups and these differences are specific to agro-ecological and socio-cultural realities.

In 2001, in Northern Burkina, Tarhule [30] found that $43 \%$ of 130 surveyed households were aware of climate information and able to access it. The percentage rose in 2006 to $66 \%$ of 130 farmers surveyed by Roncoli [8] across BF. Subsequently, the literature presents conflicting data. In Northern BF, in 2012, Zongo et al. [28] presented $26 \%$ of 386 farmers surveyed who have access to WCS and the percentage rose to $76 \%$ of 170 farmers surveyed in 2014 [29] in almost the same area. In the Sudanese Sahelian area, on the contrary, the percentage collapses to $14 \%$ of 243 surveyed farmers in 2012 [28]. Our study is not directly comparable with previous results, the sample being designed for an ex-post counterfactual evaluation, which settles an average of $86 \%$ of pilot farmers in two consecutive years having regular access during the whole season to understandable WCS.

\subsection{Uptake}

Quantitative information about uptake does not exist in the literature for BF and is very scarce generally for sub-Saharan Africa. Many factors affect the uptake of WCS, including socio-cognitive constraints [36], disconnection between producers and users [36,37] and disagreement between traditional and scientific knowledge [38,39]. The first barrier is the language, WCS should be available in local languages and formulated in a clear and simple manner [31]. A simple translation is often not sufficient, WCS should be reinterpreted, possibly linking with traditional knowledge and indigenous forecasting methods which are often highly trusted [39]. Roncoli [8] demonstrated that training increases farmers understanding of and trust in WCS. The second aspect is the support; written messages cannot be understood by illiterate farmers, while vocal communications (by radio or even instant messaging or telephone) are much easier to understand by a wider public. Our study confirms that rural radios are still the best option to reach farmers in rural areas. A third aspect emerging is that trust is built over time. During the three years of the study, WCS provided by ANAM gained credibility and therefore the uptake by farmers increased. Even if no quantitative information is available specifically on uptake, our data account for $86 \%$ of pilot farmers declaring to correctly understand the WCS to which they have access.

\subsection{Action}

Access and comprehensibility of WCS are not sufficient to ensure action by farmers. The timing of WCS delivery to communities affects the ability to use it because it should be consistent and linked time wise to specific agronomic practices [21,40]. Very often, farmers complain about late forecasts that are no longer useful when received. Nowadays, information and communication technologies help to reduce this time gap; regardless, other challenges persist, such as the spatial scale. WCS need to be downscaled at an appropriate scale for decision-making. If the user is the farmer, the information should be relevant to his/her plot. Even when the information is decision relevant for farmers, and it is received and understood, there may be other barriers to the utilization in decisionmaking. The more common case is that farmers do not have access to the inputs that are recommended (i.e., seeds, fertilizers, pesticides) because of local availability or high prices or access to credit.

In Burkina Faso, Roncoli in 2006 [8] found that $60.7 \%$ of pilot farmers took relevant action in field preparation and $50.6 \%$ in crops and varieties selection, while Zongo [28] found in 2012 that in Sudano-Sahelian areas of Burkina Faso 73.5\% of farmers receiving the information used it. Our study confirms slightly higher percentages ranging from $82 \%$ for meteorological forecasts, to $84 \%$ for climate forecasts use for rainfed cereals (sorghum). The adoption is still much lower (55\%) for market gardeners.

Another aspect of taking action is related to gender. According to a review of several studies, Gumucio et al. [35] assert that the division of labor by gender as well as the resource control and decision-making power can affect the capacities of women to act on WCS. Our study does not address those factors that condition women's and men's use of 
weather and climate information but it shows that women have slightly less access to WCS compared to men.

\subsection{Impacts}

Ex-post impact evaluations of WCS in Burkina Faso are scarce. Ouédraogo et al. [27] report that on-farm gains associated with the use of SF increased cowpea farmers yields by $24 \%$. Information recipients were shown to have made decisions that resulted in savings in seed and inputs, which led to gross margin gains (66\%).

Our study on a larger sample (300) and on two years, indicates that costs of sorghum production are reduced by $40 \%$, sorghum yields are increased by $41 \%$ and gross benefit increased by $267 \%$. Our findings compared to previous studies suggest that the use of WCS in the agriculture sector is gaining momentum in Burkina Faso with direct evidence of impacts in terms of increased yields and economic benefits. Moreover, on the environmental level, our study demonstrates that WCS allows a reduction of 50\% in the use of fertilizers, resulting in a net decrease in soil and groundwater pollution. Another important environmental impact comes from avoiding plowing or weeding before heavy rains using weather forecasts. Indeed, heavy rains on plowed or weeded fields cause strong soil erosion and sediment transport into the drainage network. Our research also confirms what Vaughan stated analyzing 66 studies on WCS evaluation in Africa [3]: a majority of farmers use WCS when they are accessible, credible and useful.

\subsection{Limits of the Study}

Intrinsic characteristics of WCS pose limits to their evaluation [3,17]. The first concerns the non-exclusionary nature of WCS, which can be easily accessible through informal networks and media. This implies that distinguishing a treated and control population can be challenging. In order to overcome this challenge, we assumed that a treated population were those who had been trained in the use of WCS. The second aspect concerns climatic variability, which affects not only the final impact (yield) but also the need for WCS and the incremental benefit. Indeed, WCS are more useful in drought years rather than in rainy ones, and an above normal situation could reduce the willingness of farmers to search for and use WCS. We developed our research over two cropping seasons, the first having been normal and the second largely above normal; this means that obtained results could be even more evident in the case of a below normal rainy season. Moreover, more robust results could be obtained with a longer time series better representing different weather and climatic condition. Besides, the counterfactual approach adopted for the impact assessment reduces the bias due to interannual climate variability, as demonstrated by the OLS regressions, when the variable "year" is included. Finally, the impact of WCS results from the interaction of many decisions and depends on farmers' goals, skills, and constraints. Therefore, it can be difficult to isolate the contribution of WCS from the other factors affecting yields and or economic benefits. The counterfactual approach used in this study and the large sample aimed to minimize the influence of such external factors.

\section{Conclusions}

WCS cannot be evaluated as a simple product, but they need to be addressed as a process through which producers and users engage to identify needs, develop procedures, test and refine the service, including broadcasting channels and also establishing long-term relationships and trust [9]. Defining goals, priorities, responsibilities, expectations are part of the success of such a process. Multiple actors are involved, i.e., NMHSs personnel, agriculture extension officers, media and farmers, and their collaboration and cooperation facilitate the adoption of [21] and trust in WCS [41]. The evidence suggests that in Burkina Faso barriers to the uptake and use of WCS have been overcome, building a collaborative environment enabling farmers to fully profit from weather and climate information. This research shows that farmers use WCS mainly for choosing crop varieties and sowing dates, and that climate information is most useful when farmers have access to appropriate 
response options such as improved crop varieties and quality seeds, which could further boost crop yields. WCS also help to rationalize expenses and working time. Farmers are avoiding wasting seeds or fertilizer due to predicted rainfall as well as the wrong time to plow and weed, which could lead to erosion, or an immediate re-emergence of weeds. The reduction of fertilizers use has also positive environmental effects reducing water and soil salinization. Moreover, some farmers in Tenado are trying to assess their debt capacity for the cropping season based on seasonal forecasts.

Nevertheless, in order to scale-up WCS in West Africa barriers and enablers to the use of climate information need to be further explored, particularly related to gender issues. New approaches are needed identify the role these factors play in influencing access and use across different production systems and cultural environments. According to Vaughan et al. [3], communication strategies (e.g., messaging, visualization, etc.) and dissemination mechanisms (e.g., radio, SMS, social media, etc.) are critical factors whose role needs to be further studied. Moreover, the sustainability of WCS over time has rarely been evaluated and new business models for WCS in SSA released from the development projects approach should be explored.

Author Contributions: Conceptualization, V.T.; methodology, V.T. and H.C.; formal analysis, V.T., H.C. and S.B.; investigation, H.C., G.B. and C.S.; resources, J.-B.M. and J.C.; writing-original draft preparation, V.T.; writing—review and editing, H.C., G.B., J.C., P.M.N. and J.-B.M.; supervision, V.T. and J.C.; project administration, J.-B.M. and P.M.N.; funding acquisition, J.-B.M. and J.C. All authors have read and agreed to the published version of the manuscript.

Funding: This research was funded by the CREWS Initiative through the CREWS Burkina Faso Project, grant number CREWS/CProj/03/Burkina, realized by the World Meteorological Organization (WMO) in Burkina Faso in collaboration with the Burkina Faso National Meteorological Agency (ANAM).

Institutional Review Board Statement: Not applicable.

Informed Consent Statement: Not applicable.

Data Availability Statement: The data presented in this study are openly available in [Zenodo] at https:/ / doi.org/10.5281/zenodo.5541239 (accessed on 30 September 2021). Hamidou Coulibaly, Gregoire Baki, Cyriaque Sia, José Camacho, \& Vieri Tarchiani. (2021). Dataset of impacts of weather and climate services on farming in Burkina Faso 2019 and 2020 [Data set].

Acknowledgments: The authors express their sincere thanks to the Agence Nationale de la Météorologie of Burkina Faso in the persons of Ernest Ouedraogo, former Director General, and Joel Zoungrana, current Director General, for their continuous support in carrying out the research activities.

Conflicts of Interest: The authors declare no conflict of interest. The funders had no role in the design of the study; in the collection, analyses, or interpretation of data; in the writing of the manuscript, or in the decision to publish the results. 


\section{Appendix A}

Table A1. The effect of training on yields controlling for covariates, coefficients of OLS regression.

\begin{tabular}{ccc}
\hline & $\mathbf{( 1 )}$ & $\mathbf{( 2 )}$ \\
\cline { 2 - 3 } & Yields (kg) & Yields (kg) \\
\hline Pilot & $408.319 * * *$ & $397.121 * * *$ \\
& $(9.987)$ & $(50.582)$ \\
Seeds $(\mathrm{kg})$ & & 0.252 \\
& & $(1.327)$ \\
Fertilizer $(\mathrm{kg})$ & & 0.124 \\
& & $(0.641)$ \\
Working days & & -1.106 \\
year_20 & & $(0.928)$ \\
Constant & $991.987 * * *$ & $(22.214)$ \\
Observations & $(6.929)$ & $1105.902 * * *$ \\
R-squared & 603 & $(122.605)$ \\
\end{tabular}

Note: The coefficient ( $\beta_{2}$ in Equation (1)) of Pilot variable measures the difference in the mean of the values of the dependent variables (columns) between the control and treatment groups; Robust standard errors in parentheses; *** $p<0.01,{ }^{* *} p<0.05, * p<0.1$.

\section{References}

1. Hansen, J.W.; Mason, S.J.; Sun, L.; Tall, A. Review of seasonal climate forecasting for agriculture in sub-Saharan Africa. Exp. Agric. 2011, 47, 205-240. [CrossRef]

2. FAO. Global Outlook on Climate Services in Agriculture - Investment Opportunities to Reach the Last Mile; FAO: Rome, Italy, 2021; 137p. [CrossRef]

3. Vaughan, C.; Hansen, J.; Roudier, P.; Watkiss, P.; Carr, E. Evaluating agricultural weather and climate services in Africa: Evidence, methods, and a learning agenda. WIREs Clim. Chang. 2019, 10, 586. [CrossRef]

4. Tarchiani, V.; Rossi, F.; Camacho, J.; Stefanski, R.; Mian, K.; Pokperlaar, D.; Coulibaly, H.; Sitta Adamou, A. Smallholder Farmers Facing Climate Change in West Africa: Decision-Making between Innovation and Tradition. J. Innov. Econ. Manage. 2017, 24, 151-176. [CrossRef]

5. Campbell, B.M.; Thornton, P.; Zougmoré, R.; van Asten, P.; Lipper, L. Sustainable intensification: What is its role in climate smart agriculture? Curr. Opin. Environ. Sustain. 2014, 8, 39-43. [CrossRef]

6. Vaughan, C.; Dessai, S. Climate services for society: Origins, institutional arrangements, and design elements for an evaluation framework. Wiley Interdiscip. Rev. Clim. Chang. 2014, 5, 587-603. [CrossRef] [PubMed]

7. WMO. Status of Human Resources in National Meteorological and Hydrological Services; ETR-21; WMO: Geneva, Switzerland, 2017; 75p, Available online: https:/ / library.wmo.int/doc_num.php?explnum_id=4184 (accessed on 23 November 2020).

8. Roncoli, C.; Jost, C.; Kirshen, P.; Sanon, M.; Ingram, K.T.; Woodin, M.; Somé, L.; Ouattara, F.; Sanfo, B.J.; Sia, C.; et al. From accessing to assessing forecasts: An end-to-end study of participatory climate forecast dissemination in Burkina Faso (West Africa). Clim. Chang. 2009, 92, 433-460. [CrossRef]

9. Vincent, K.; Daly, M.; Scannell, C.; Leathes, B. What can Climate Services learn from theory and practice of co-production? Clim. Serv. 2018, 12, 48-58. [CrossRef]

10. Oyekale, A.S. Access to risk mitigating weather forecasts and changes in farming operations in East and West Africa: Evidence from a baseline survey. Sustainability 2015, 7, 14599-14617. [CrossRef]

11. Amegnaglo, C.J.; Asomanin, K.; Mensah-bonsu, A. Contingent valuation study of the benefits of seasonal climate forecasts for maize farmers in the Republic of Benin, West Africa. Clim. Serv. 2017, 6, 1-11. [CrossRef]

12. Yegbemey, R.N.; Egah, J. Reaching out to smallholder farmers in developing countries with climate services: A literature review of current information delivery channels. Clim. Serv. 2021, 23, 100253. [CrossRef]

13. Mase, A.S.; Prokopy, L.S. Unrealized Potential: A review of perceptions and use of weather and climate information in agricultural decision making. Weather Clim. Soc. 2014, 6, 47-61. [CrossRef]

14. Tarchiani, V.; Camacho, J.; Coulibaly, H.; Rossi, F.; Stefanski, R. Agrometeorological services for smallholder farmers in West Africa. Adv. Sci. Res. 2018, 15, 15-20. [CrossRef]

15. Bremer, S.; Wardekker, A.; Dessai, S.; Sobolowski, S.; Slaattelid, R.; van der Sluijs, J. Toward a multi-faceted conception of co-production of climate services. Clim. Serv. 2019, 13, 42-50. [CrossRef]

16. Bacci, M.; Ousman Baoua, Y.; Tarchiani, V. Agrometeorological Forecast for Smallholder Farmers: A Powerful Tool for WeatherInformed Crops Management in the Sahel. Sustainability 2020, 12, 3246. [CrossRef]

17. Tall, A.; Coulibaly, J.Y.; Diop, M. Do climate services make a difference? A review of evaluation methodologies and practices to assess the value of climate information services for farmers: Implications for Africa. Clim. Serv. 2018, 11, 1-12. [CrossRef]

18. Vogel, J.; Letson, D.; Herrick, C. A framework for climate services evaluation and its application to the Caribbean Agrometeorological Initiative. Clim. Serv. 2017, 6, 65-76. [CrossRef] 
19. Collier, P.; Dercon, S. African Agriculture in 50 Years: Smallholders in a rapidly changing world? World Dev. 2014, 63, 92-101. [CrossRef]

20. Sonwa, D.J.; Dieye, A.; El Mzouri, E.; Majule, A.; Mugabe, T.; Omolo, N.; Wouapi, H.; Obando, J.; Brooks, N. Drivers of climate risk in African agriculture. Clim. Dev. 2017, 9, 383-398. [CrossRef]

21. Nkiaka, E.; Taylor, A.; Dougill, A.J.; Antwi-Agyei, P.; Fournier, N.; Bosire, E.N.; Konte, O.; Lawal, K.A.; Mutai, B.; Mwangi, E.; et al. Identifying user needs for weather and climate services to enhance resilience to climate shocks in sub-Saharan Africa. Environ. Res. Lett. 2019, 14, 123003. [CrossRef]

22. Tall, A.; Kristjanson, P.; Chaudhury, M.; Mckune, S.; Zougmore, R. Who Gets the Information? Gender, Power and Equity Considerations in the Design of Climate Services for Farmers; CCAFS Working Paper No. 89; CGIAR Research Program on Climate Change, Agriculture and Food Security (CCAFS): Copenhagen, Denmark, 2014; 76p, Available online: https: / cgspace.cgiar.org/ bitstream/handle/10568/49673/CCAFS\%20WP\%2089.pdf (accessed on 18 February 2021).

23. Stigter, C.J.; Tan, Y.; Das, H.P.; Zheng, D.; Rivero Vega, R.E.; Van Viet, N.; Bakheit, N.I.; Abdullahi, Y.M. Complying with farmers conditions and needs using new weather and climate information approaches and technologies. In Managing Weather and Climate Risks in Agriculture; Sivakumar, M.V.K., Motha, R., Eds.; Springer: Berlin, Germany, 2007. [CrossRef]

24. Stigter, C.J. A Decade of Capacity Building Through Roving Seminars on Agro-Meteorology/-Climatology in Africa, Asia and Latin America: From Agrometeorological Services via Climate Change to Agroforestry and Other Climate-Smart Agricultural Practices. In Implementing Climate Change Adaptation in Cities and Communities; Leal Filho, W., Adamson, K., Dunk, R., Azeiteiro, U., Illingworth, S., Alves, F., Eds.; Springer: Cham, Switzerland, 2016. [CrossRef]

25. Perrels, A.; Nurmi, V.; Nurmi, P. Weather service chain analysis (WSCA): An approach for appraisal of the social-economic benefits of improvements in weather services. In Proceedings of the 16th International Road Weather Conference, Helsinki, Finland, 23-25 May 2012; SIRWEC: Helsinki, Finland, 2012. Available online: http:/ /www.sirwec2012.fi/Extended_Abstracts/002_Perrels.pdf (accessed on 23 March 2021).

26. Duflo, E.; Glennerster, R.; Kremer, M. Using randomization in development economics research: A toolkit. In Handbook of Development Economics; Schultz, T.P., Strauss, J.A., Eds.; Elsevier: Amsterdam, The Netherlands, 2007; Volume 4, pp. $3895-3962$. [CrossRef]

27. Ouédraogo, M.; Zougmoré, R.; Barry, S.; Somé, L.; Grégoire, B. The Value and Benefits of Using Seasonal Climate Forecasts in Agriculture: Evidence from Cowpea and Sesame Sectors in Climate-Smart Villages of Burkina Faso; CCAFS: Wageningen, Netherlands, 2015; Available online: https:/ / cgspace.cgiar.org/handle/10568/68537 (accessed on 1 April 2021).

28. Zongo, B.; Diarra, A.; Barbier, B.; Zorom, M.; Yacouba, H.; Dogot, T. Farmers' perception and willingness to pay for climate information in Burkina Faso. J. Agric. Sci. 2016, 8, 175-187. [CrossRef]

29. Ouédraogo, M.; Barry, S.; Zougmoré, R.B.; Partey, S.T.; Somé, L.; Baki, G. Farmers' willingness to pay for climate information services: Evidence from cowpea and sesame producers in Northern Burkina Faso. Sustainability 2018, 10, 611. [CrossRef]

30. Tarhule, A.; Lamb, P.J. Climate research and seasonal forecasting for West Africans: Perceptions, dissemination, and use? Bull. Am. Meteorol. Soc. 2003, 84, 1741-1759. [CrossRef]

31. Ochieng, J.; Kirimi, L.; Ochieng, D.O.; Njagi, T.; Mathenge, M.; Gitau, R.; Ayieko, M. Managing climate risk through crop diversification in rural Kenya. Clim. Chang. 2020, 162, 1107-1125. [CrossRef]

32. Ouedraogo, I.; Diouf, N.S.; Ouédraogo, M.; Ndiaye, O.; Zougmoré, R.B. Closing the gap between climate information producers and users: Assessment of needs and uptake in Senegal. Climate 2018, 6, 13. [CrossRef]

33. Carr, E.; Onzere, S.N. Really Effective (For 15\% of the Men): Lessons in Understanding and Addressing User Needs in Climate Services from Mali. Clim. Risk Manag. 2018, 22, 82-95. [CrossRef]

34. Carr, E.R.; Owusu-Daaku, K.N. The shifting epistemologies of vulnerability in climate services for development: The case of Mali's agrometeorological advisory programme. Area 2016, 48, 7-17. [CrossRef]

35. Gumucio, T.; Hansen, J.; Huyer, S.; van Huysen, T. Gender-responsive rural climate services: A review of the literature. Clim. Dev. 2020, 12, 241-254. [CrossRef]

36. Singh, C.; Dorward, P.; Osbahr, H. Developing a holistic approach to the analysis of farmer decision-making: Implications for adaptation policy and practice in developing countries. Land Use Policy 2016, 59, 329-343. [CrossRef]

37. Lemos, M.C.; Kirchhoff, C.J.; Ramprasad, V. Narrowing the climate information usability gap. Nat. Clim. Chang. 2012, 2, 789. [CrossRef]

38. Roncoli, C.; Ingram, K.; Kirshen, P. Reading the rains: Local knowledge and rainfall forecasting among farmers of Burkina Faso. Soc. Nat. Resour. 2002, 15, 411-430. [CrossRef]

39. Jiri, O.; Mafongoya, P.L.; Mubaya, C.; Mafongoya, O. Seasonal climate prediction and adaptation using indigenous knowledge systems in agriculture systems in Southern Africa: A review. J. Agric. Sci. 2016, 8, 156. [CrossRef]

40. Lemos, M.C.; Finan, T.J.; Fox, R.W.; Nelson, D.R.; Tucker, J. The use of seasonal climate forecasting in policymaking: Lessons from Northeast Brazil. Clim. Chang. 2002, 55, 479-507. [CrossRef]

41. Stigter, K.; Winarto, Y.T.; Ofori, E.; Zuma-Netshiukhwi, G.; Nanja, D.; Walker, S. Extension agrometeorology as the answer to stakeholder realities: Response farming and the consequences of climate change. Atmosphere 2013, 4, 237-253. [CrossRef] 